\title{
Carbon, nitrogen, hydrogen and sulphur components of intertidal caprellids (Crustacea) from southern Spain
}

\author{
José M. Guerra-García*, M. Pilar Cabezas, Elena Baeza-Rojano, \\ Isabel Pacios-Palma, J. Carlos García-Gómez
}

Laboratorio de Biología Marina, Departamento de Fisiología y Zoología, Facultad de Biología, Universidad de Sevilla, 41012 Sevilla, Spain

\begin{abstract}
Carbon $(\mathrm{C})$, hydrogen $(\mathrm{H})$, nitrogen $(\mathrm{N})$ and sulphur $(\mathrm{S})$ contents were measured in the most common caprellid species inhabiting intertidal ecosystems of southern Spain (Caprella acanthifera, C. danilevskii, C. dilatata, C. equilibra, C. grandimana, C. hirsuta, C. liparotensis and C. penantis). Five gammarid species (Ampithoe sp., Apherusa sp., Hyale perieri, H. schmidtii and Jassa marmorata), 3 isopods (Dynamene edwardsi, Idotea chelipes and Ischyromene lacazei) and the tanaid Tanais dulongii were also collected for comparisons. Univariate analyses showed that S content was significantly higher in caprellids (mean $\pm \mathrm{SD}_{i} 1.5 \pm 0.3 \%$ ) than in gammarids $(1.1 \pm 0.1 \%$ ), isopods $(0.9 \pm 0.2 \%)$ and tanaids $(0.9 \pm 0.3 \%)$, and $\mathrm{N}$ showed significantly higher concentrations in caprellids $(6.0 \pm 0.9 \%)$ and gammarids $(6.2 \pm 0.5 \%)$ than in isopods $(5.2 \pm 0.8 \%)$ and tanaids $(5.4 \pm$ $0.4 \%$ ). The average of the $\mathrm{C}$ and $\mathrm{H}$ contents by dry weight was $27.2 \pm 3.1$ and $4.6 \pm 0.4 \%$, respectively, in caprellids, $28.2 \pm 2.3$ and $4.7 \pm 0.3 \%$ in gammarids, $26.8 \pm 3.0$ and $4.2 \pm 0.5 \%$ in isopods and $26.4 \pm 2.0$ and $4.2 \pm 0.3 \%$ in tanaids. The first axis of the principal component analysis associated with the concentrations for the 17 peracaridan species accounted for $69.7 \%$ of the total variance and correlated significantly with $\mathrm{C}, \mathrm{H}$ and $\mathrm{N}$, while the second axis accounted for $25.1 \%$ of the variance and correlated with S. Caprellid females showed higher concentrations of $\mathrm{C}, \mathrm{H}, \mathrm{N}$ and $\mathrm{S}$ than males, but analysis of variance only showed significant differences in the percentage of $\mathrm{C}$ and $\mathrm{H}$. The higher $\mathrm{C}$ and $\mathrm{H}$ contents in females could reflect a larger accumulation of lipids in the body and could be related to reproduction and differences in feeding habitats between males and females.
\end{abstract}

KEY WORDS: Carbon · Hydrogen · Nitrogen · Sulphur · Peracarid crustaceans · Southern Spain Resale or republication not permitted without written consent of the publisher

\section{INTRODUCTION}

In temperate shallow-water ecosystems where dense algal cover occurs, caprellid amphipods are considered to play a major role as secondary producers (Takeuchi 1998). They form an important trophic link between primary producers and higher trophic levels. For some finfish species (including some commercially exploited food and ornamental aquarium species), caprellids are an important, and in some instances the dominant, nat- ural dietary component (Woods 2009). Recently, several studies have shown the importance of caprellids in applied studies. A field approach showed that caprellids could be used as bioindicators of physico-chemical measures (Guerra-García \& García-Gómez 2001), and Caprella spp. may be well-suited for monitoring butyltin residue changes over small spatial and temporal scales (see Takeuchi et al. 2001, Ohji et al. 2002, Aono \& Takeuchi 2008). C. penantis has been successfully used as an indicator of trace metal contamination in 
intertidal ecosystems (Guerra-García et al. 2009a). Furthermore, caprellid amphipods are an overlooked marine finfish aquaculture resource and could be potentially an excellent group to be used in integrated co-culture and intensive culture (Woods 2009): (1) caprellids are a natural food source for many fishes; (2) they can possess relatively high levels of desirable polyunsaturated fatty acids, particularly eicosapentaenoic acid (20:5n-3) and docosahexaenoic acid (22:6n-3), both of which have high nutritional value (see also Guerra-García et al. 2004); (3) they occur globally from the polar regions to the tropics, with many littoral species having cosmopolitan distributions; (4) they can attain high population densities and biomass; (5) they can readily colonise artificial structures, sometimes at higher densities than natural surrounding substratum; (6) they can exhibit fast growth with short generation times; (7) they appear to be opportunistic feeders capable of using a variety of feeding techniques, and (8) some caprellid species possess wide environmental tolerances.

In spite of this increasing interest of using caprellids in applied approaches, there is a lack of basic studies exploring the composition of main elements $(\mathrm{C}, \mathrm{H}, \mathrm{N}$, S). Takeuchi (1998) investigated the carbon and nitrogen components of 4 caprellids (Caprella danilevskii, C. penantis, C. subinermis and C. verrucosa) inhabiting the Sargassum yezoense community of northeastern Japan. Average percentages of carbon and nitrogen contents of the total dry weight ranged from 30.8 to $32.2 \%$ and 5.8 to $6.8 \%$ respectively, with the carbon:nitrogen ration decreasing with increasing caprellid size. Apart from this study, no others have dealt with the organically bound elements in caprellids and other related peracaridan crustaceans. In fact, our knowledge of the carbon and nitrogen contents is based mostly on planktonic crustaceans and decapods, especially crabs (e.g. Omori \& Ikeda 1984, Anger \& Moreira 2004, Parrish et al. 2005, Bas et al. 2007)

\section{MATERIALS AND METHODS}

For this study, 18 rocky shore stations were selected along the Atlantic and Mediterranean coasts of southern Spain (Fig. 1). Eight caprellid species were selected for the study (Caprella acanthifera, C. danilevskii, C. dilatata, C. equilibra, C. grandimana, C. hirsuta, C. liparotensis and C. penantis). Besides the caprellid species, several peracaridan crustaceans were also selected (the gammarids Ampithoe sp, Apherusa sp., Hyale perieri, H. schmidtii and Jassa marmorata, the isopods Dynamene edwardsi, Idotea chelipes and Ischyromene lacazei and the tanaid Tanais dulongii). The selected species of amphipods (caprellids and

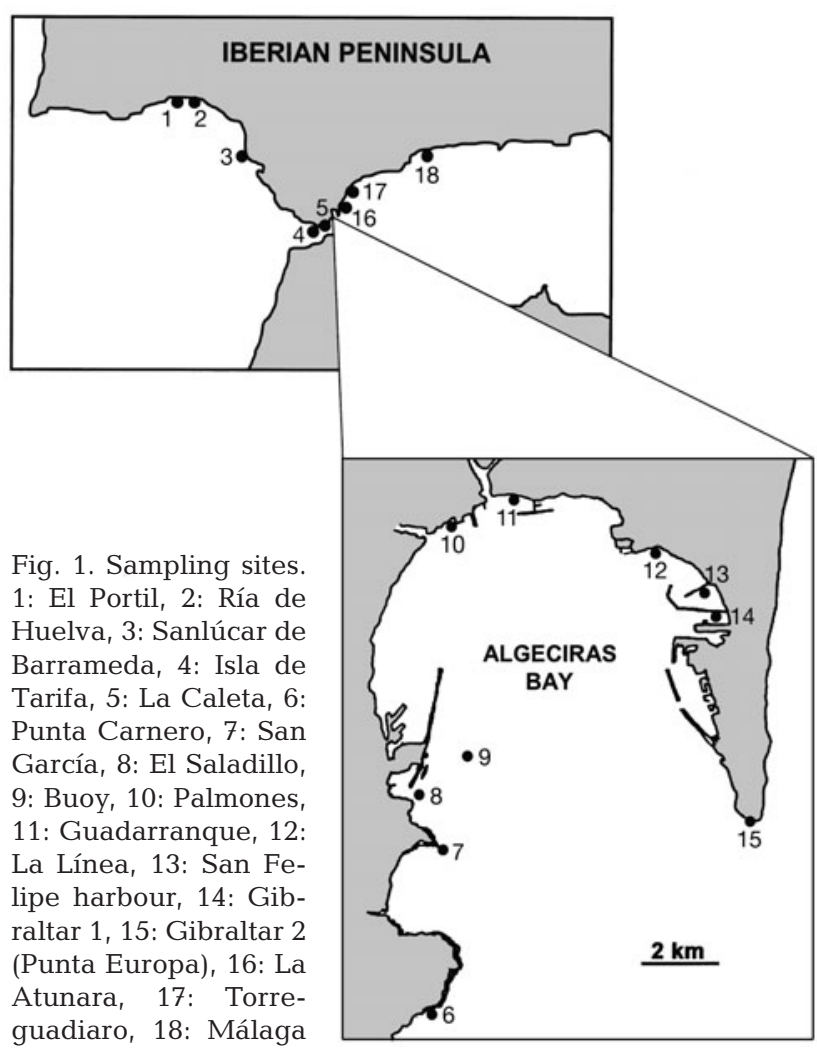

gammarids), isopods and tanaids are among the dominant taxa in intertidal communities of the Strait of Gibraltar (Guerra-García et al. 2009b). All samples were collected from the intertidal area during May and June 2008. The hydroid Tubularia crocea, the bryozoan Bugula neritina and the algae Asparagopsis armata, Corallina elongata, Gelidium latifolium, Ulva sp., Chaetomorpha sp., Jania rubens and Stypocaulum scoparium were collected. A first preliminary sorting of crustaceans was made in situ; the sample material was then transported to the laboratory in plastic containers, sorted by species and then killed by freezing. Taking into account that at least $100 \mathrm{mg}$ of dry weight are necessary for each sample to properly address the chemical protocol, adult specimens of the same species were pooled. For caprellids, males and females were kept in separate vials for further comparison. All peracaridan samples were dried at $30^{\circ} \mathrm{C}$ to a constant weight and then finely ground. The dry, powdered solid tissue was accurately weighed in a dry, pre-cleaned Teflon digestion vessel. The carbon, hydrogen, nitrogen and sulphur contents were determined with an elemental analyser (Leco model CHNS-932). Possible differences of $\mathrm{C}, \mathrm{H}, \mathrm{N}$ and $\mathrm{S}$ contents among caprellids, gammarids, isopods and tanaids were tested with a 1-way analysis of variance (ANOVA), after verifying normality using the Kolmogorov-Smirnov test, and the homo- 
Table 1. Range of concentrations (\% dry weight) of carbon (C), hydrogen (H), nitrogen (N) and sulphur (S) in the crustacean species analysed. Stations from which species were collected are also indicated (see Fig. 1). $\mathrm{n}=$ number of pools of specimens used for each species

\begin{tabular}{|c|c|c|c|c|c|c|}
\hline & Stations & $\mathrm{n}$ & $\mathrm{C}$ & $\mathrm{H}$ & $\mathrm{N}$ & $\mathrm{S}$ \\
\hline \multicolumn{7}{|l|}{ Caprellids } \\
\hline Caprella acanthifera Leach, 1814 & $4,7,17$ & 6 & $24.6-30.7$ & $4.0-5.2$ & $5.6-6.1$ & $1.4-1.8$ \\
\hline C. danilevskii Czerniavskii, 1868 & 5 & 2 & $19.7-23.6$ & $3.4-4.1$ & $4.1-5.2$ & $1.1-1.2$ \\
\hline C. dilatata Krøyer, 1843 & 1 & 2 & $28.6-32.3$ & $5.1-5.3$ & $6.7-6.8$ & $1.3-1.4$ \\
\hline C. equilibra Say, 1818 & $2,9,13$ & 6 & $24.8-33.7$ & $4.4-5.5$ & $5.9-7.1$ & $1.5-1.9$ \\
\hline C. grandimana (Mayer, 1882) & $4,8,15,17$ & 8 & $25.1-31.4$ & $3.9-5.5$ & $4.8-6.7$ & $1.1-1.9$ \\
\hline C. hirsuta Mayer, 1890 & 18 & 2 & $11.5-23.2$ & $2.7-3.9$ & $2.6-5.1$ & $1.2-1.6$ \\
\hline C. liparotensis Haller, 1879 & 12,14 & 4 & $25.5-28.4$ & $4.5-4.9$ & $5.5-6.4$ & $1.3-1.6$ \\
\hline C. penantis Leach, 1814 & $4-8,17$ & 12 & $22.3-30.9$ & $4.1-5.1$ & $5.2-6.9$ & $0.9-1.9$ \\
\hline \multicolumn{7}{|l|}{ Gammarids } \\
\hline Ampithoe sp. & 3 & 1 & 28.2 & 4.8 & 6.1 & 1.1 \\
\hline Apherusa sp. & 1 & 1 & $33.3-5.2$ & 7.5 & 0.7 & 7.9 \\
\hline Hyale perieri (Lucas, 1849) & 4 & 1 & 29.8 & 5.2 & 6.5 & 1.1 \\
\hline H. schmidtii (Heller, 1866) & $4-8,10-12,15-18$ & 11 & $22.5-36.7$ & $3.8-5.9$ & $5.0-8.7$ & $0.5-1.3$ \\
\hline Jassa marmorata Holmes, 1903 & $1,2,13$ & 3 & $26.4-27.5$ & $4.3-4.6$ & $5.9-6.2$ & $1.1-1.2$ \\
\hline \multicolumn{7}{|l|}{ Isopods } \\
\hline Dynamene edwardsi (Lucas, 1849) & 4,13 & 2 & $23.1-31.4$ & $3.7-4.9$ & $4.2-6.0$ & $1.0-1.1$ \\
\hline Idotea chelipes (Pallas, 1766) & 5,17 & 2 & $27.7-28.1$ & $4.4-4.5$ & $5.9-5.9$ & $1.1-1.1$ \\
\hline Ischyromene lacazei Racovitza, 1908 & 8,16 & 2 & $24.0-26.7$ & $3.7-3.8$ & $4.4-4.7$ & $0.6-0.9$ \\
\hline \multicolumn{7}{|l|}{ Tanaid } \\
\hline Tanais dulongii (Audouin, 1826) & $11,17,18$ & 3 & $24.5-28.6$ & $3.9-4.6$ & $5.0-5.9$ & $0.9-1.3$ \\
\hline
\end{tabular}

geneity of variances using the Levene test. For caprellids, ANOVA analyses were also conducted to explore differences between males and females. A principal component analysis (PCA) was used for the ordination of peracaridan species based on $\mathrm{C}, \mathrm{H}, \mathrm{N}$ and $\mathrm{S}$ contents. Univariate analyses were conducted with SPSS v.14, and multivariate analyses were carried out using the PC-ORD program (McCune \& Mefford 1997).

\section{RESULTS AND DISCUSSION}

Values of $\mathrm{C}, \mathrm{H}, \mathrm{N}$ and $\mathrm{S}$ measured in the 17 peracaridan species are included in Table 1. The average $( \pm \mathrm{SD})$ of the carbon and hydrogen contents by dry weight was $27.2 \pm 3.1$ and $4.6 \pm 0.4 \%$, respectively, in caprellids, $28.2 \pm 2.3$ and $4.7 \pm 0.3 \%$ in gammarids, $26.8 \pm 3.0$ and $4.2 \pm 0.5 \%$ in isopods and $26.4 \pm 2.0$ and $4.2 \pm 0.3 \%$ in tanaids (Fig. 2). Univariate analyses showed that sulphur content was significantly higher in caprellids $(1.5 \pm 0.3 \%)$ than in gammarids $(1.1 \pm$ $0.1 \%)$, isopods $(0.9 \pm 0.2 \%)$ and tanaids $(0.9 \pm 0.3 \%)$, and nitrogen showed significantly higher concentrations in caprellids $(6.0 \pm 0.9 \%)$ and gammarids $(6.2 \pm$ $0.5 \%)$ than in isopods $(5.2 \pm 0.8 \%)$ and tanaids $(5.4 \pm$ $0.4 \%$; Fig. 2). The first axis of the PCA (Fig. 3) accounted for $69.7 \%$ of the total variance and correlated significantly with $\mathrm{C}, \mathrm{H}$ and $\mathrm{N}$, while the second
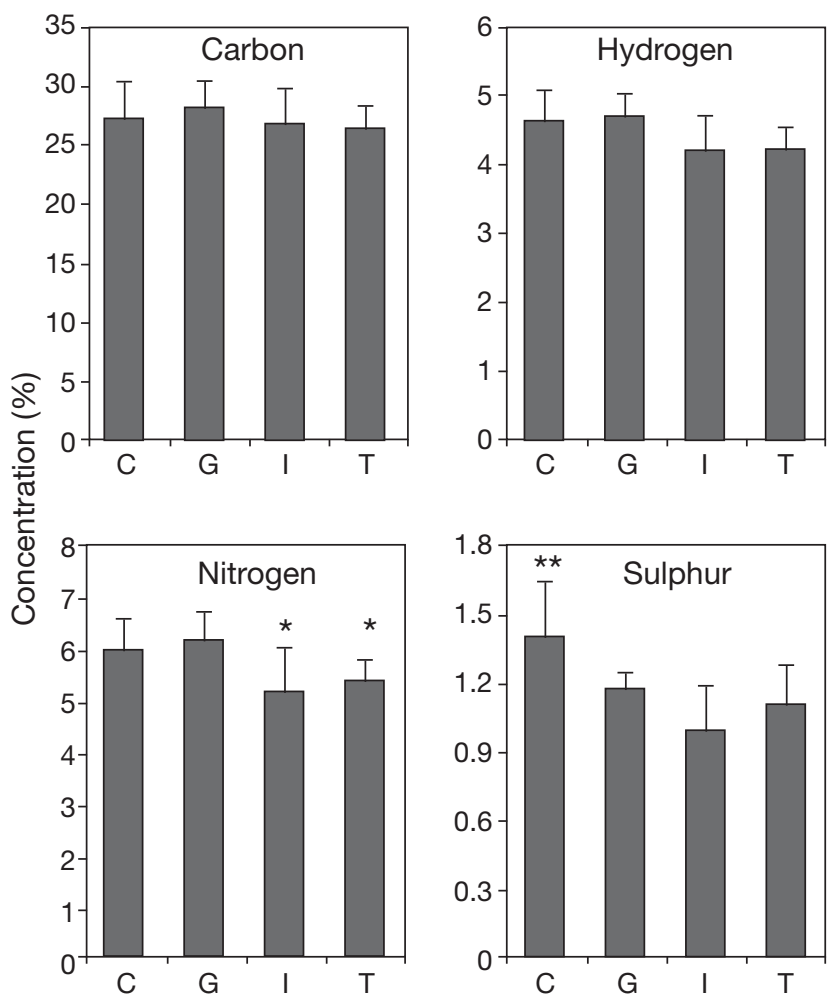

Fig. 2. Mean $( \pm \mathrm{SD})$ of carbon, hydrogen, nitrogen and sulphur concentrations in caprellids $(C, n=8)$, gammarids $(G, n=5)$, isopods ( $\mathrm{I}, \mathrm{n}=3$ ) and tanaids $(\mathrm{T}, \mathrm{n}=1)(\mathrm{n}=$ no. of species). All data are expressed in $\%$. ${ }^{*} \mathrm{p}<0.05,{ }^{* *} \mathrm{p}<0.01$ 


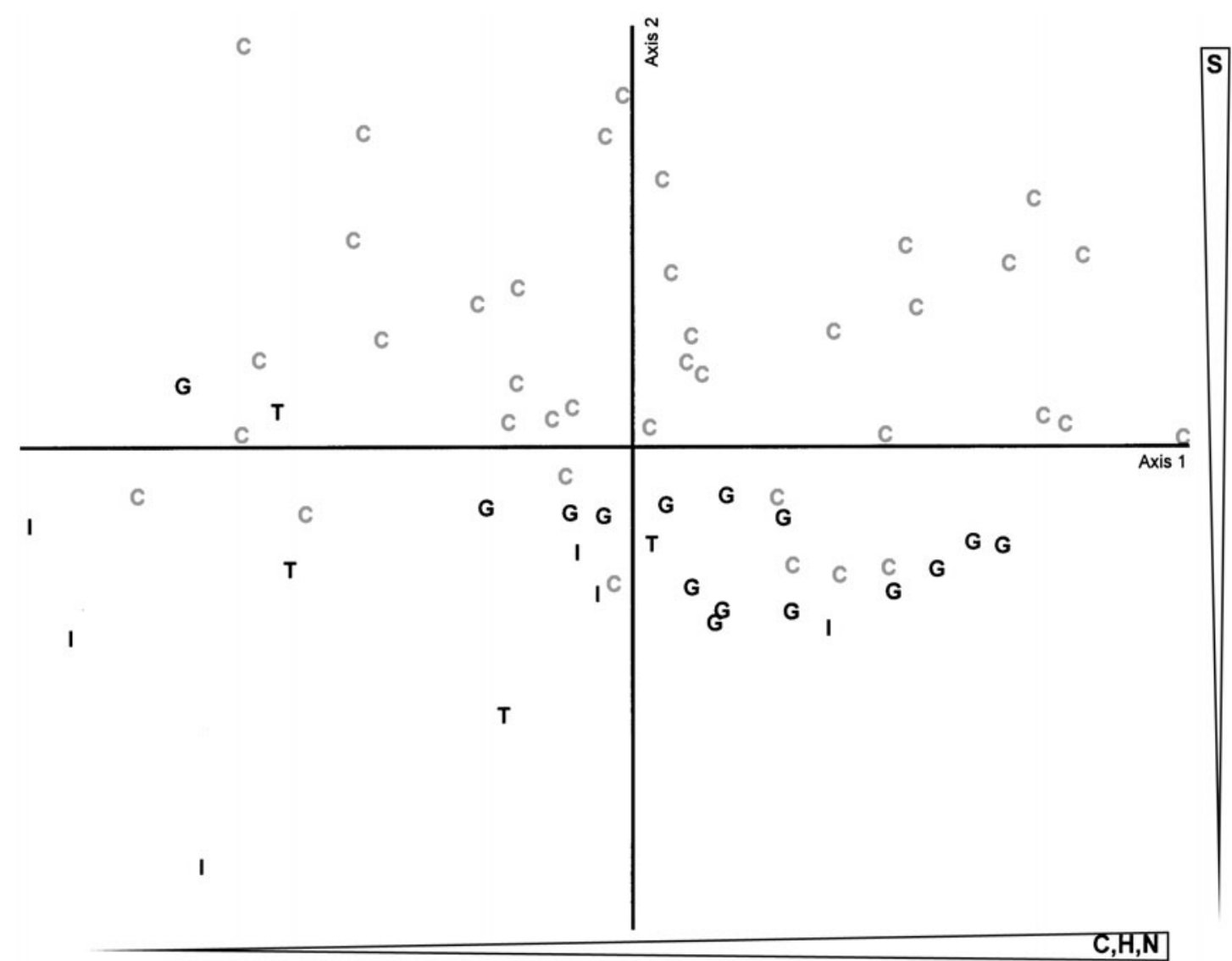

Fig. 3. Principal component analysis based on concentrations of carbon, hydrogen, nitrogen and sulphur in all the studied samples of the 17 peracaridan species considered. C: caprellids (grey), G: gammarids, I: isopods, T: tanaids

axis absorbed $25.1 \%$ of the variance and correlated with S. The higher contents of S in caprellids clearly separated this group in the positive part of Axis 2 . Regarding Axis 1, caprellids were distributed throughout the whole axis, while gammarids were dominant in the positive part of the axis and tanaids and isopods in the negative part, characterised by lower concentrations of $\mathrm{C}, \mathrm{H}$ and $\mathrm{N}$ (Fig. 3).

This is the first study reflecting different compositions of macroelements among different groups of peracaridan crustaceans. Further studies are necessary to explain the lower $\mathrm{N}$ content found in isopods and tanaids, and the higher content of $\mathrm{S}$ in caprellids. Nitrogen is an essential part of amino acids and nucleic acids, and sulphur is also an essential component of several key amino acids, vitamins and the crustacean exoskeleton. Several key enzyme systems such as coenzyme A depend, for their activity, on free sulphydril groups. Isopods and tanaids are likely characterised by a different pool of proteins, and caprellids could show some differences regarding enzymatic activities in comparison to other peracaridan groups. On the other hand, concentrations of $\mathrm{C}$ and $\mathrm{N}$ in the caprellid species considered in our study were slightly lower than in Japanese species studied by Takeuchi (1998). In Japan, Caprella danilevskii showed $32.2 \pm$ $4.6 \%(\mathrm{C})$ and $5.8 \pm 1.2 \%(\mathrm{~N})$ and C. penantis $30.8 \pm$ $3.2 \%(\mathrm{C})$ and $6.9 \pm 1.4 \%(\mathrm{~N})$, while individuals of these species from southern Spain in our study had values of $21.6 \pm 1.9 \%(\mathrm{C})$ and $4.6 \pm 0.5 \%(\mathrm{~N})$ for $C$. danilevskii and $26.6 \pm 2.8 \%(\mathrm{C})$ and $6.0 \pm 0.5 \%(\mathrm{~N})$ for $C$. penantis. Ikeda (1974) studied the carbon and nitrogen contents of planktonic crustaceans collected from various localities of the North Pacific and concluded that the carbon content depended on habitat temperatures: the carbon contents of boreal zooplankton reach $65 \%$ of the dry weight in several species, while in tropical and subtropical planktons carbon content is less than $45 \%$. In fact, higher carbon contents can reflect a larger accumulation of lipids in the body (Omori \& Ikeda 1984) and higher $\mathrm{C}: \mathrm{N}$ ratios indicate higher lipid content (Bas et al. 2007). However, the Japanese material was based on summer collections made at seawater temperatures of 18 to $23^{\circ} \mathrm{C}$, and our collections in southern Spain were also based on similar summer temperatures, ranging from $17.2^{\circ} \mathrm{C}$ (Stn 15) to $24.1^{\circ} \mathrm{C}$ (Stn 3). Consequently, factors other than temperature, such as type of diet and patterns of reproduction, could be 


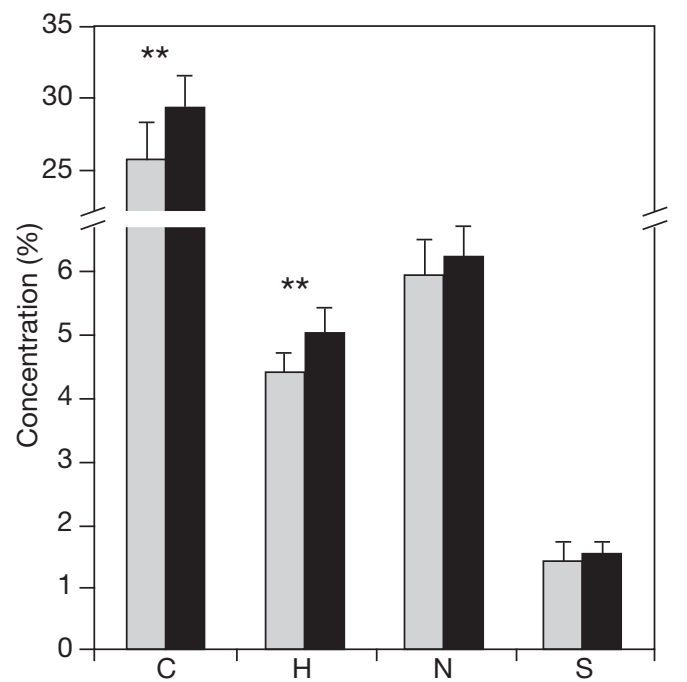

Fig. 4. Mean $( \pm \mathrm{SD})$ of carbon $(\mathrm{C})$, hydrogen $(\mathrm{H})$, nitrogen $(\mathrm{N})$ and sulphur (S) concentrations in male (grey bars) and female (black bars) caprellids. Data are expressed in $\% .{ }^{* *} \mathrm{p}<0.01$

involved in the different concentrations of $\mathrm{C}$ and $\mathrm{N}$ among locations.

For caprellids, females showed higher concentrations of $\mathrm{C}, \mathrm{H}, \mathrm{N}$ and $\mathrm{S}$ than males, although ANOVA only reflected significant differences in the percentage of $\mathrm{C}$ and $\mathrm{H}$ (Fig. 4). Takeuchi (1998) also found that, proportionally for the same length of pereonite 2, carbon and nitrogen contents were significantly higher in large females than in males. The higher carbon and hydrogen contents in females could reflect a larger accumulation of lipids in the body and could be related to reproductive purposes (e.g. accumulation of lipid reserves in egg yolk) and differences in feeding habitats between males and females. Guerra-García et al. (2004) found also sex-related differences in fatty acid composition in caprellid species of southern Spain, with higher contents of 16:1n-7 in females. Further studies should be conducted to confirm these sexrelated differences in caprellids, and the biological significance of higher contents of $\mathrm{C}$ and $\mathrm{H}$ in females.

Acknowledgements. Financial support for this work was provided by the Ministerio de Educación y Ciencia (Project CGL2007-60044/BOS) co-financed by FEDER funds, and by the Consejería de Innovación, Ciencia y Empresa, Junta de Andalucía (Project P07-RNM-02524). Two anonymous referees provided helpful comments to improve the manuscript.

Editorial responsibility: Hans Heinrich Janssen, Oldendorf/Luhe, Germany

\section{LITERATURE CITED}

Anger K, Moreira GS (2004) Biomass and elemental composition of eggs and larvae of a mangrove crab, Sesarma rectum Randall (Decapoda: Sesarmidae) and comparison to a related species with abbreviated larval development. Sci Mar 68:117-126

Aono A, Takeuchi I (2008) Effects of tributyltin at concentrations below ambient levels in seawater on Caprella danilevskii (Crustacea: Amphipoda: Caprellidae). Mar Pollut Bull 57:515-523

> Bas CC, Spivak ED, Anger K (2007) Seasonal and interpopulational variability in fecundity, egg size, and elemental composition (CHN) of eggs and larvae in a grapsoid crab, Chasmagnathus granulatus. Helgol Mar Res 61:225-237

> Guerra-García JM, García-Gómez JC (2001) Spatial distribution of Caprellidea (Crustacea: Amphipoda): a stress bioindicator in Ceuta (North Africa, Gibraltar area). PSZN I Mar Ecol 22:357-367

> Guerra-García JM, Martínez-Pita I, Pita ML (2004) Fatty acid composition of the Caprellidea (Crustacea: Amphipoda) from the Strait of Gibraltar. Sci Mar 68:501-510

> Guerra-García JM, Baeza-Rojano E, Cabezas MP, Díaz-Pavón JJ, Pacios I, García-Gómez JC (2009a) The amphipods Caprella penantis and Hyale schmidtii as biomonitors of trace metal contamination in intertidal ecosystems of Algeciras Bay, southern Spain. Mar Pollut Bull 58:783-786

Guerra-García JM, Cabezas MP, Baeza-Rojano E, Espinosa F, García-Gómez JC (2009b) Is the north side of the Strait of Gibraltar more diverse than the south side? A case study using the intertidal peracarids (Crustacea: Malacostraca) associated to the seaweed Corallina elongata. J Mar Biol Assoc UK 89:387-397

Ikeda T (1974) Nutritional ecology of marine zooplankton. Mem Fac Fish Hokkaido Univ 22:1-97

McCune B, Mefford MJ (1997) PC-ORD. Multivariate analysis of ecological data. MJM Software Design, Gleneden Beach, OR

- Ohji M, Takeuchi I, Takahashi S, Tanabe S, Miyazaki N (2002) Differences in the acute toxicities of tributyltin between the Caprellidea and the Gammaridea (Crustacea: Amphipoda). Mar Pollut Bull 44:16-24

Omori M, Ikeda T (1984) Methods in marine zooplankton ecology. Wiley-Interscience, New York

Parrish CC, Thompson RJ, Deibel D (2005) Lipid classes and fatty acids in plankton and settling matter during the spring bloom in a cold ocean coastal environment. Mar Ecol Prog Ser 286:57-68

Takeuchi I (1998) Dry weight, carbon and nitrogen components of caprellid amphipods (Crustacea) inhabiting the Sargassum yezoense community of Otsuchi Bay, northeastern Japan. Mar Biol 130:417-423

Takeuchi I, Takahasi S, Tanabe S, Miyazaki N (2001) Caprella watch: a new approach for monitoring butyltin residues in the ocean. Mar Environ Res 52:97-113

> Woods CMC (2009) Caprellid amphipods: an overlooked marine finfish aquaculture resource? Aquaculture 289: $199-211$

Submitted: August 20, 2009; Accepted: November 18, 2009

Proofs received from author(s): December 17, 2009 